\title{
Prevalence of HTLV-1 infection in northeast of Iran
}

\author{
Reza Farid", Farhad Farid, Safai A Rezaee \\ From 17th International Conference on Human Retroviruses: HTLV and Related Viruses \\ Trois Ilets, Martinique. 18-21 June 2015
}

Northeast of Iran is a new endemic. Area for HTLV-1 and for the first time. Farid and his Immunology Dep at Mashhad University published paper and then Farid and safae in Aids research and human Retro virology volt 12 November 12 1996. Published prevalence of HTLV-1 in Iran several. Publication describes the prevalence of HTLV-1 in Jewish individuals born in city of Mashhad Iran. Then we reported serological and generic studies in the non Jewish population of Mashhad as well as Neishabour. Seropositive rate of HTLV-1 in Mashhad is 3.0\% (21of 694). DNA sequence were amplified by PCR directly from the fresh PRMCs of seropositive individuals from Mashhad. Phylogenetic analysis of the viral DNA sequence indicated that HTLV-1 in Mashhad belong to the cosmopolite clade. ATL and HAM/TSP is common in the northeast of Iran.

Published: 28 August 2015

doi:10.1186/1742-4690-12-S1-O7

Cite this article as: Farid et al:: Prevalence of HTLV-1 infection in northeast of Iran. Retrovirology 2015 12(Suppl 1):O7.

* Correspondence: rfaridh@gmail.com

Department of Neurology, Mashhad University of Medical Sciences, Iran

Submit your next manuscript to BioMed Central and take full advantage of:

- Convenient online submission

- Thorough peer review

- No space constraints or color figure charges

- Immediate publication on acceptance

- Inclusion in PubMed, CAS, Scopus and Google Scholar

- Research which is freely available for redistribution 